\title{
Pharmacological Activities of Natural Products Derived from Clerodendrumin fortunatum $\mathrm{L}$
}

Rashid MA*, Jubair MH and Atiqur Rahman

Department of Applied Chemistry and Chemical Engineering, Islamic University, Kushtia-7003, Bangladesh

DOI: $10.36347 /$ sjet.2020.v08i08.003

| Received: 16.08.2020 | Accepted: 24.08.2020 | Published: 28.08.2020

*Corresponding author: Dr. Md. Mamun Al Rashid

Abstract

Original Research Article

The antioxidant property of the methanol and ethanol extracts from various parts of Clerodendrum infortunatum L. was examined in vitro. Antioxidant activity was evaluated by using 1, 1-diphenyl-2-picrylhydrazyl (DPPH) assay. The free radical scavenging activity of ethyl acetate fraction was superior to all other fractions $\left(\mathrm{IC}_{50}=16.45 \mu \mathrm{g} / \mathrm{ml}\right), \mathrm{which}$ was higher than synthetic antioxidant butylate dhydroxy anisole, BHA, $(18.27 \mu \mathrm{g} / \mathrm{ml})$. Furthermore, the amount of total phenolic compounds was determined and its content in EtOAc fraction (12.25\%) was the highest as compared to other extract or fractions. The essential oil and organic extracts also showed potent antibacterial activities against the tested bacteria such as Escherichia coli ATCC 35218, Methicillin-resistant Staphylococcus aureus (isolate), Klebsiella pneumoniae ATCC 700603, Pseudomonas aeruginosa ATCC 27853 and Enterococcus faecalis ATCC 291212. Our study suggests that natural products derived from Clerodendrumin fortunatum L. have the potential to be used as food preservatives.

Keywords: Clerodendrum infortunatum L.; Antioxidant activity; Antiobiotic activity; DPPH.

Copyright @ 2020: This is an open-access article distributed under the terms of the Creative Commons Attribution license which permits unrestricted use, distribution, and reproduction in any medium for non-commercial use (NonCommercial, or CC-BY-NC) provided the original author and source are credited.

\section{INTRODUCTION}

There is a growing interest in research on food components such as phenolic compounds because of their possible linkage to health benefits, e.g., reduction of heart disease and cancer, based on their antioxidant activity [1]. Many medicinal plants contain large amount of antioxidants such as polyphenols, which have an important role in preventing a variety of stressrelated diseases and aging because these are closely related to the active oxygen and lipid peroxidation [2]. Antioxidants have been used for the prevention and treatment of free radical-related disorders [3]. However, there have been concerns about synthetic antioxidants such as butylate dhydroxy anisole (BHA) and butylate dhydroxy toluene (BHT) because of their possible activity as promoters of carcinogenesis [4]. Consequently, there is a scientific interest to find naturally occurring antioxidants for using as natural preservative ingredients in foods or medicinal materials to replace synthetic antioxidants, which are being restricted due to their carcinogenicity [5].

Among the plants known for medicinal value, the plants of genus Clerodendrum belonging to family Lamiacea are very important for their therapeutic potentials. C. infortunatum L. known as Vati flower in Bengali.

Several ethno botanical surveys show that $C$. infortunatum was among the plants reported to be used traditionally to treat bacterial infections such as enteric diseases i.e., diarrhea, dysentery and other gastrointestinal infections; upper respiratory tract infections associated with coughing pneumonia, asthma and bronchitis; urogenital infections including sexually transmitted diseases, skin infections (dermatitis, eczema, scabies), wounds and ulcers; headache, ophthalmic, insect bites, nasal bleeding, stroke, measles, paludism; and bacterial fevers such as typhoid fever and diabetes and veterinary problems [6,7]. It is also used in the treatment of epilepsy, shigellosis, trypanosomiasis, convulsion, pile and anaemia [8]. It is also implicated in the oral hygiene and veterinary $[9$, 10]. Comprehensive biological activities of $C$. infortunatum have been reviewed [7] and it is associated with a wide variety of biological activities [11-14].

For the production of energy to fuel through biological processes oxidation is essential in many living organisms. However, oxygen-centered free 
radicals and other reactive oxygen species (ROS), which are continuously, produced in vivo, result in cell death and tissue damage. The role of oxygen radicals has been implicated in several diseases, including cancer, diabetes and cardiovascular diseases, ageing, etc. [15]. Antioxidant has been used for the prevention and treatment of free radical related disorders. Antioxidants halt the free radical chain reactions. Some antioxidants are themselves free radicals, donating electrons to stabilize and neutralize the dangerous free radicals. Other antioxidants work against the molecules that form free radicals, destroying them before they can begin the domino effect that leads to oxidative damage. However there have been concerns about synthetic antioxidants such as ascorbic acid because of possible activity as promoters of carcinogenesis. Synthetic antioxidants, such as butylate dhydroxy anisole (BHA) and butylate dhydroxy toluene (BHT), also have restricted to use in foods as they are suspected to be carcinogenic [16]. Therefore, the importance of searching natural antioxidants has greatly increased in recent years $[17,18]$. The pharmaceutical industry is undertaking the rapid development and use of natural antioxidants, especially those of plant origin, to replace synthetic drug. Moreover, essential oils are plant secondary metabolites, mainly monoterpenes, sesquiterpenes and their corresponding oxygenated derivatives, which have been showed various pharmacological effects, such as antimicrobial, antioxidant, spasmolytic, carminative, hepato protective, antiviral and anti-carcinogenic effects $[19,20]$. Although it remains unclear which of the compounds, of medicinal plants are the active ones, phenolics recently have received increasing attention because of some interesting new findings regarding their biological activities [21]. From pharmacological and therapeutic points of view, the antioxidant properties of phenolics, such as free radical scavenging and inhibition of lipid peroxidation, are the most crucial. Even though a variety of herbs and plants are known to be the sources of phenolic compounds, studies isolating phenolics and evaluating their anti oxidative effects have rarely been carried out [21, 22].

\section{MATERIALS AND METHODS}

Samples (Clerodendrumin fortunatum $\mathrm{L}$ ) were collected from Kawraid, Sreepur, Gazipur area of the Bangladesh during May to June, 2017. The plants were identified by Ahasan Kabir Rana, Associate Professor, Botany, Kushtia Govt. College, Kushtia, Bangladesh on the basis of morphological features and the voucher specimen no. 40701 have been deposited in the Bangladesh National herbarium, Dhaka.

The air-dried flower of Clerodendrum infortunatum $\mathrm{L}$ powdered $(50 \mathrm{~g})$ were extracted with ethanol and methanol separately at room temperature for 7 days and the solvents were evaporated by vacuum rotary evaporator. The extraction process yielded in methanol (4.5 g) and ethanol (6.4 g) extracts.

\section{ANTIOXIDANT ASSAY}

Free radical scavenging capacity

The antioxidant activity of the methanol and ethanol extract from various parts of Clerodendrum infortunatum $L$. were measured on the basis of the scavenging activities of the stable 1,1-diphenyl-2picrylhydrazyl (DPPH) free radical [23] (Cuendet, Hostettmann, \&Potterat, 1997). Various concentrations of $100 \mu \mathrm{l}$ of test extract or fractions were added to $3 \mathrm{ml}$ of a $0.004 \%(\mathrm{w} / \mathrm{v})$ methanol solution of DPPH. After 30 min of incubation period in the dark at room temperature, the absorbance was measured against a blank at $517 \mathrm{~nm}$. Inhibition of free radical DPPH in percent $(\%)$ was calculated by the formula:

Percentage inhibition $\left.(\%)=\left[\left(A_{\text {blank }}-A_{\text {sample }}\right) / A_{\text {blank }}\right)\right] \times$ 100

Where, $A_{\text {blank }}$ is the absorbance of the control reaction (containing all reagents except test compound), and $A_{\text {sample }}$ is the absorbance of the test compound. $\mathrm{IC}_{50}$ values (concentration of sample required to scavenge $50 \%$ of free radicals) were calculated from the regression equation, prepared from the concentration of the extract or fractions and percentage inhibition of free radical formation/ percentage inhibition DPPH was assayed. Synthetic antioxidant reagents, butylate dhydroxy anisole (BHA) and L-ascorbic acid, were used as positive controls and all tests were carried out in triplicate.

\section{Determination of total phenolics}

Total phenolic constituent of the aforementioned extracts were determined by FolinCiocalteu reagent in alkaline medium [24] and was expressed as gallic acid equivalents (GAE). Different concentrations of gallic acid were prepared in $80 \%$ methanol. $100 \mu \mathrm{l}$ test sample (from a range of concentrations) was taken in a cuvette, then $1 \mathrm{ml}$ of distilled water and $500 \mu \mathrm{l}(1 / 10$ dilution) of the FolinCiocalteu reagent was added, and cuvette was shaken thoroughly. After $1 \mathrm{~min}, 1500 \mu \mathrm{l}$ of $20 \%$ sodium carbonate $\left(\mathrm{Na}_{2} \mathrm{CO}_{3}\right)$ solution was added. The final mixture was shaken and then incubated for $2 \mathrm{~h}$ in the dark at room temperature. The absorbance of samples was measured at $760 \mathrm{~nm}$ and the results were expressed in $\mathrm{mg}$ of gallic acid/ $\mathrm{g}$ (GAE) of dry weight of samples.

\section{Antibacterial activity assay Bacterial strains \\ Escherichia coli ATCC 35218, Methicillin- resistant Staphylococcus aureus (isolate), Klebsiella pneumoniae ATCC 700603, Pseudomonas aeruginosa ATCC 27853 and Enterococcus faecalis ATCC 291212 were used in this study. These bacteria were cultured using Nurtient Broth (LabM Limited, UK) and Bacteriological Agar No.1 (LabM Limited, UK) at $37^{\circ} \mathrm{C}$ for $24 \mathrm{~h}$. Microorganisms are kindly provided by Assoc. Prof. Dr. Sezer OKAY, Cankiri Karatekin University, Faculty of Science Department of Biology, Cankiri Turkey.}




\section{Disc diffusion assay}

The essential oil was diluted 1:5 (v/v) with methanol and sterilized by filtration using $0.22 \mu \mathrm{m}$ sterile Millipore filter (Millipore Corp., Billerica, MA, USA) and aliquots of $10 \mu \mathrm{Lwere}$ spotted onto the sterile What man No. 1 filter paper discs (6 mm diameter); while the extracts were dissolved in the same solvent used for their extraction and $10 \mu$ Lof $30 \mathrm{mg} \mathrm{mL}^{-1}$ of each organic extract $\left(300 \mu \mathrm{g} \mathrm{disc}{ }^{-1}\right)$ was applied on the filter paper discs and placed on the inoculated LB agar medium. Then the antibacterial test was carried out as described [20] using $100 \mu \mathrm{L}$ of standardized inoculums suspension containing $10^{7} \mathrm{CFUmL}^{-1}$ of bacteria. Negative controls were prepared using the same solvents employed to dissolve the samples. Standard antibiotic streptomycin $\left(10 \mu \mathrm{g} \mathrm{disc}{ }^{-1}\right)$ from SigmaAldrich Co., St. Louis, MO, USA) was used as positive control for the tested bacteria. The plates were incubated micro aerobically at $37{ }^{\circ} \mathrm{C}$ for 24 . Antibacterial activity was evaluated by measuring the diameter of the zones of inhibition against the tested bacteria. Each assay in this experiment was replicated three times.

\section{Minimum inhibitory concentration (MIC)}

The minimum inhibitory concentration (MIC) of the essential oil and various extracts was assessed according to Chandrasekaran and Venkatesalu [21]. Active cultures for MIC determination were prepared by transferring a loopful of cells from the stock cultures to flasks and inoculated in LB medium and incubated at $37{ }^{\circ} \mathrm{C}$ for $24 \mathrm{~h}$. The sampleswere incorporated into LB broth medium to get the final concentration ranging from 0 to $1000 \mu \mathrm{g} \mathrm{mL}^{-1}$. Finally, $20 \mu \mathrm{L}$ inoculums of each bacteria strain $\left(10^{7} \mathrm{CFUmL}^{-1}\right)$ was transferred to each tube and the tests were performed in a volume of $2 \mathrm{~mL}$. The control tube contained only organisms and not the samples. The culture tubes were incubated at $37{ }^{\circ} \mathrm{C}$ for $24 \mathrm{~h}$. The lowest concentration of the test samples, which did not show any visual growth of tested organisms after macroscopic evaluation, was determined as MIC, which was expressed in $\mu \mathrm{g} \mathrm{mL}^{-1}$.

\section{RESULTS AND DISCUSSION Antioxidant Results}

Table-1: Total phenolic compounds of Clerodendrum infortunatum L. extracts

\begin{tabular}{|l|c|}
\hline Extracts & Total phenolic $(\mathbf{m g ~ G A E} / \mathbf{g ~ d w})^{\mathbf{a}}$ \\
\hline Methanol extract & $71.63 \pm 2.2$ \\
\hline Hexane fraction & $24.87 \pm 1.8$ \\
\hline Chloroform fraction & $39.43 \pm 0.8$ \\
\hline
\end{tabular}

Table-2: DPPH scavenging activities of $C$. infortunatum $\mathrm{L}$. in methanolic and ethanolic extract

\begin{tabular}{|l|l|l|l|l|}
\hline Extract & Used part & Conc. $\boldsymbol{\mu g} / \mathbf{m l}$ & Inhibition $\%$ & IC $_{\mathbf{5 0}}$ Value \\
\hline \multirow{5}{*}{ Methanol Extract } & Leaf & 100 & $71.56 \pm 1.2$ & 10.35 \\
\cline { 2 - 5 } & & 150 & $85.21 \pm 1.5$ & \\
\cline { 2 - 5 } & & 200 & $96.12 \pm 1.1$ & \\
\cline { 2 - 5 } & Stem & 100 & $69.38 \pm 1.2$ & 15.27 \\
\cline { 2 - 5 } & & 150 & $80.47 \pm 1.3$ & \\
\cline { 2 - 5 } & & 200 & $92.14 \pm 1.4$ & \\
\cline { 2 - 5 } & Root & 100 & $55.15 \pm 1.5$ & 72.24 \\
\cline { 2 - 5 } & & 150 & $69.67 \pm 0.5$ & \\
\cline { 2 - 5 } & & 200 & $77.64 \pm 1.5$ & \\
\cline { 2 - 5 } & Leaf & 100 & $67.23 \pm 1.7$ & 22.41 \\
\cline { 2 - 5 } & & 150 & $81.45 \pm 1.6$ & \\
\cline { 2 - 5 } & & 200 & $90.54 \pm 1.4$ & \\
\cline { 2 - 5 } & Stem & 100 & $65.14 \pm 1.3$ & 36.05 \\
\cline { 2 - 5 } & & 150 & $81.15 \pm 1.1$ & \\
\cline { 2 - 5 } & & 200 & $90.54 \pm 0.5$ & \\
\cline { 2 - 5 } & Root & 100 & $48.12 \pm 0.7$ & 104.43 \\
\cline { 2 - 5 } & & 150 & $61.11 \pm 1.2$ & \\
\cline { 2 - 5 } & 200 & $68.14 \pm 1.2$ & \\
\hline
\end{tabular}




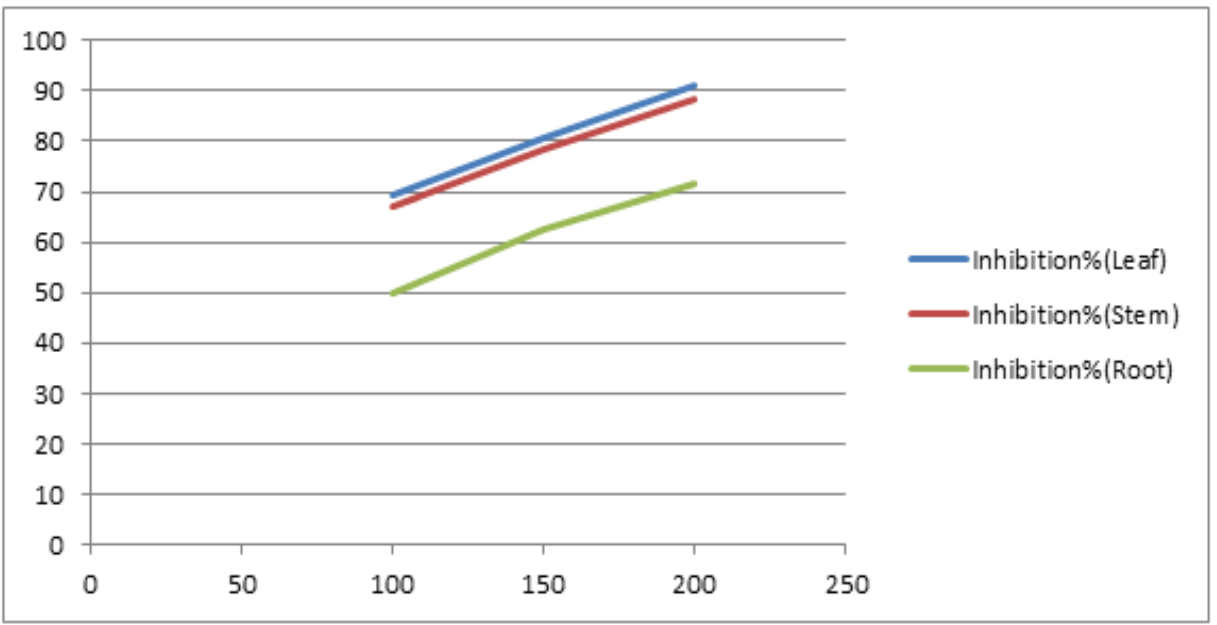

Fig-1: DPPH scavenging activities of Clerodendrum infortunatum L. in methanolic extract.

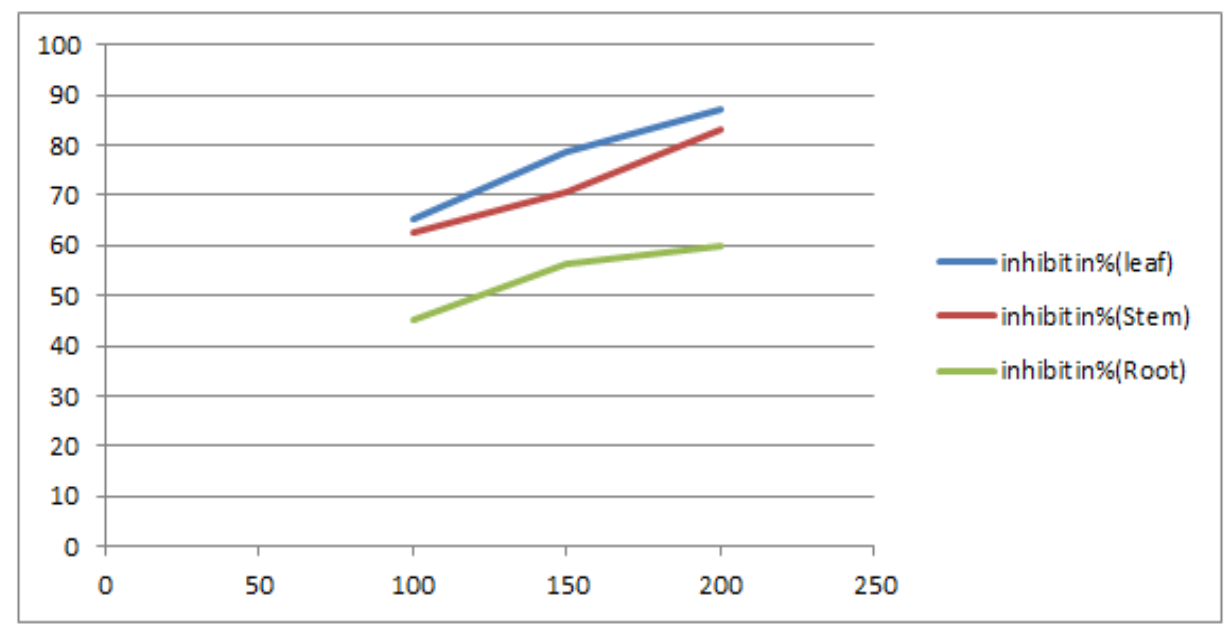

Fig-2: DPPH scavenging activities of Clerodendrum infortunatum L. in ethanolic extract

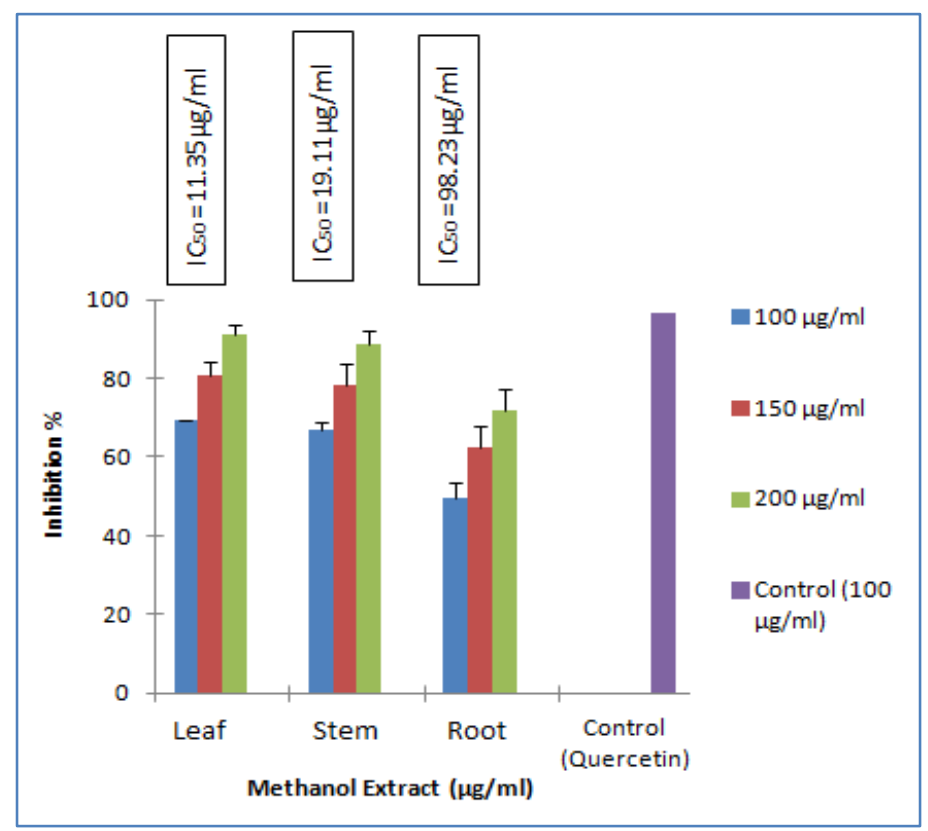

Fig-3: DPPH scavenging activities of Clerodendrum infortunatum $\mathrm{L}$. in methanolic extracts 


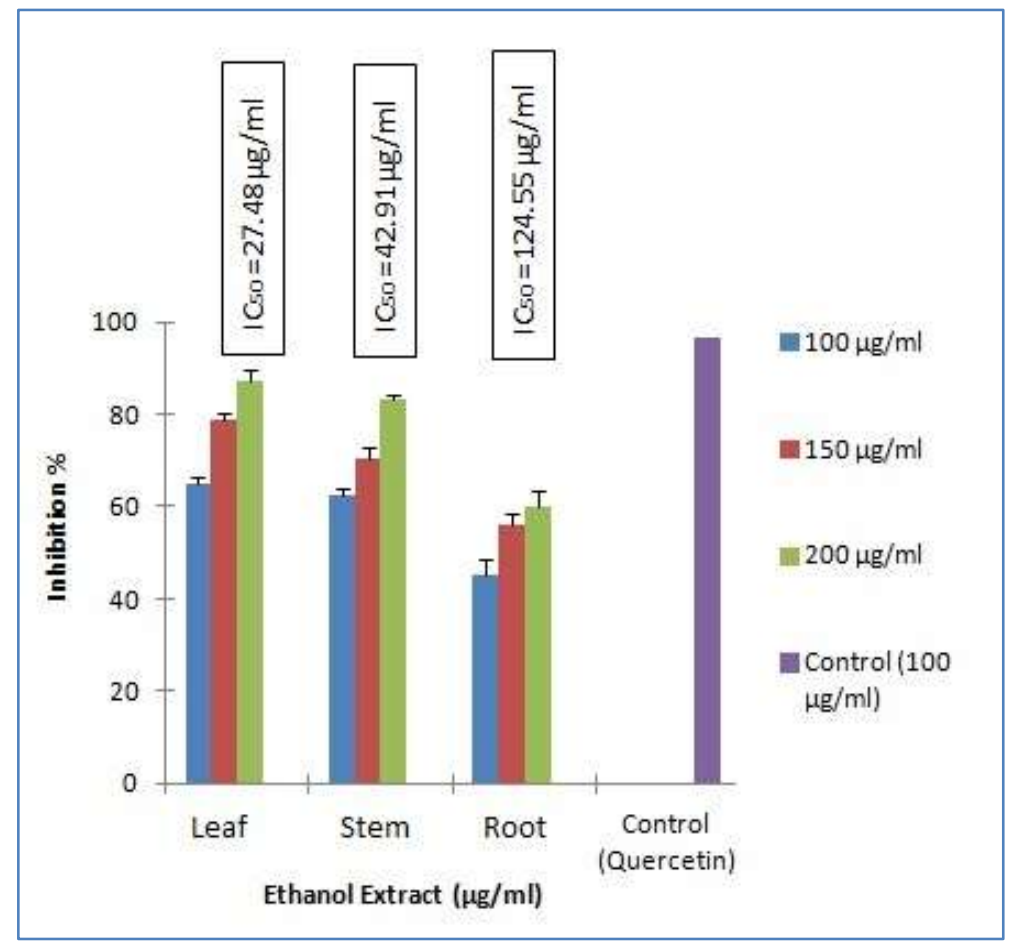

Fig-4: DPPH scavenging activities of Clerodendrum infortunatum L. in ethanolic extracts

Antioxidant has been used for the prevention and treatment of free radical related disorders. However there have been concerns about synthetic antioxidants such as ascorbic acid because of possible activity as promoters of carcinogenesis. There is a scientific interest to find naturally occurring antioxidants for use in foods to replace synthetic antioxidants.

In this study we found that crude extracts of Clerodendrum infortunatumL. Enrich in phenolic compounds (table !.) have strong DPPH scavenging activities. The antioxidant effect of these extracts is due to the presence of phenolic or alcoholic components [25]. The antioxidant activity is to be mainly due to their redox properties which can play an important role in adsorbing and neutralizing free radicals, quenching singlet and triplet oxygen or decomposing peroxides. The DPPH free radical scavenging activity of leaves, stems and roots extracts have been shown in Fig.1.2,3 and Fig.4. The $\mathrm{IC}_{50}$ values were compared with the $\mathrm{IC}_{50}$ value of Quercetin (positive control). A lower $\mathrm{IC}_{50}$ value indicates a greater antioxidant activity. In methanol and ethanol the $\mathrm{IC}_{50}$ values of leaves of Clerodendruminfortunatum L. were recorded $11.35 \mu \mathrm{g} /$ and $27.48 \mu \mathrm{g} / \mathrm{ml}$, respectively (table2.).

Free radical scavenging activity of methanol and ethanol extracts measured by DPPH assay, is shown in Fig. 1. Their activity of the plant extracts is concentration dependent and lower $\mathrm{IC}_{50}$ valuereflects better protective action. The $\mathrm{IC}_{50}$ valuesof methanol and ethanol extracts were recorded in the range of 10.35 to
$104.43 \mu \mathrm{g} / \mathrm{ml}$. Methanol extract exhibited stronger DPPH scavenging activity than ethanol extract. The free radical scavenging activity of methanol extract $\left(\mathrm{IC}_{50}=\right.$ $10.35 \mu \mathrm{g} / \mathrm{ml}$ ) was superior to all other extract. The $\mathrm{IC}_{50}$ value of methanol extract $\left(\mathrm{IC}_{50}=10.35 \mu \mathrm{g} / \mathrm{ml}\right)$ was lower than synthetic antioxidant, butylated hydroxyanisole (BHA) (18.27 $\mu \mathrm{g} / \mathrm{ml})$. Therefore, methanol extract showed higher activity than butylated hydroxyanisole. The strongest activity of methanol extract may be related to its higher phenolic content (71.63 mg GAE/g) as measured by gallic acid test (Table 1).

\section{Antibacterial activity}

The isolated essential oil and organic extracts (chloroform, EtOAc and $\mathrm{MeOH}$ ) were dissolved in DMSO to make the required concentration $\left(10 \mu \mathrm{L} \mathrm{disc}^{-1}\right.$ correspond to $\left.50 \mu \mathrm{g} \mathrm{disc}{ }^{-1}\right)$. Then the antibacterial test was carried out as described ${ }^{20}$ using $100 \mu \mathrm{L}$ of standardized inoculums suspension containing $10^{7}$ $\mathrm{CFUmL}^{-1}$ of bacteria including Escherichia coli ATCC 35218, Methicillin-resistant Staphylococcus aureus (isolate), Klebsiell apneumoniae ATCC 700603, Pseudomonas aeruginosa ATCC 27853 and Enterococcus faecalis ATCC 291212.As shown in Table 16, all these compounds displayed potent antibacterial activities against all the tested bacteria. Standard antibiotics; tetracycline $\left(30 \mu \mathrm{g} \mathrm{disc} \mathrm{d}^{-1}\right)$, streptomycin $\left(30 \mu \mathrm{g} \mathrm{disc} \mathrm{d}^{-1}\right)$ and erythromycin $(15 \mu \mathrm{g}$ $\left.\operatorname{disc}^{-1}\right)$ were used as positive controls, whereas DMSO was used as negative control. As a blind control, DMSO did not show any effect of this study (data not shown). 
Table-3: Antibacterial activity of essential oil and organic extracts of Clerodendrum infortunatum $\mathrm{L}$

\begin{tabular}{|c|c|c|c|c|c|c|c|}
\hline \multirow{3}{*}{ Bacteria } & \multicolumn{6}{|c|}{ Zone of growth inhibition in mm } \\
\cline { 2 - 8 } & \multicolumn{6}{|c|}{ Extracts $^{\mathbf{2}}$} & \multicolumn{2}{c|}{ Standard antibiotics } \\
\cline { 2 - 8 } & Chloroform & EtOAc & $\mathrm{MeOH}$ & EO & TE & ST & ER \\
\hline EC & $14 \pm 0.6$ & $15 \pm 0.5$ & $18 \pm 0.5$ & $22 \pm 0.5$ & $24 \pm 0.7$ & $16 \pm 0.5$ & $13 \pm 0.9$ \\
\hline MRSA & $13 \pm 0.5$ & $12 \pm 0.7$ & $15 \pm 0.4$ & $16 \pm 0.4$ & $29 \pm 1.1$ & $23 \pm 0.5$ & $25 \pm 0.7$ \\
\hline KP & $19 \pm 1.1$ & $18 \pm 1.2$ & $23 \pm 1.2$ & $24 \pm 1.2$ & $13 \pm 0.5$ & $16 \pm 0.9$ & $10 \pm 0.5$ \\
\hline PA & $17 \pm 0.7$ & $17 \pm 0.5$ & $23 \pm 0.5$ & $21 \pm 0.5$ & $32 \pm 1.5$ & $32 \pm 1.2$ & $25 \pm 1.2$ \\
\hline EF & $19 \pm 0.6$ & $18 \pm 0.8$ & $21 \pm 0.7$ & $22 \pm 0.7$ & $12 \pm 0.6$ & $18 \pm 1.1$ & $12 \pm 0.5$ \\
\hline
\end{tabular}

Values are given as mean \pm S.D of triplicate experiment.

${ }^{\mathrm{a}}$ Diameter of inhibition zones $(\mathrm{mm})$ of the essential oil and organic extracts around the discs $(6 \mathrm{~mm})$ impregnated with $10 \mu \mathrm{L} \mathrm{disc}{ }^{-1}$ correspond to $50 \mu \mathrm{g} \mathrm{disc}^{-}$ 1. Standard antibiotics: TE, Tetracycline $\left(30 \mu \mathrm{g} \mathrm{disc}{ }^{-1}\right)$;
ST, streptomycin (30 $\left.\mu \mathrm{g} \mathrm{disc}{ }^{-1}\right)$; ER, erythromycine(15 $\left.\mu \mathrm{g} \operatorname{disc}^{-1}\right)$. Bacteria: EC, Escherichia coli ATCC 35218; MRSA, Methicillin-resistant Staphylococcus aureus (is olate); KP, Klebsiella pneumoniae ATCC 700603; PA, Pseudomonas aeruginosa ATCC 27853; EF, Enterococ cus faecalis ATCC 291212.

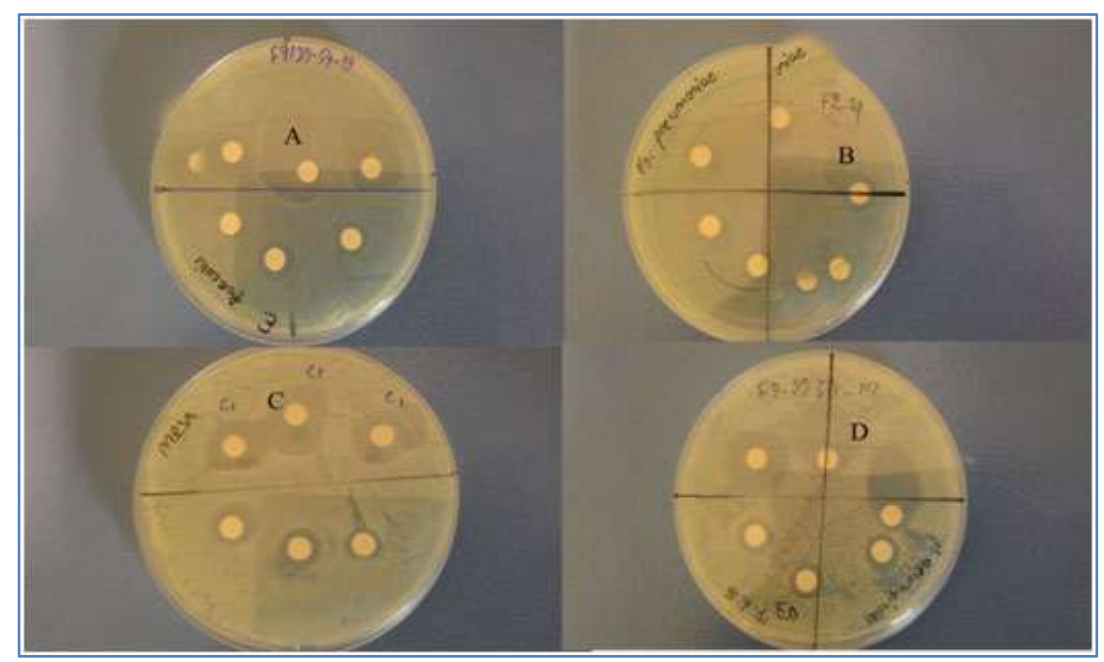

Fig-5: Diameter of inhibition zones (mm) of $\left(50 \mu \mathrm{g} \mathrm{disc}^{-1}\right)$ : A) Chloroform; B) EtOAc; C) Essential Oil; D) MeOH

\section{ACKNOWLEDGEMENTS}

This work was carried out with support of "Research Project of the University Grants Commission, Government of the People's Republic of Bangladesh (Project No. 6(75)/UGC/RSP/Sci.\&Tech./Bio (33)/4462)".

\section{REFERENCES}

1. Seeram NP, Schutzki R, Chandra A, Nair MG. Char acterization, quantification, and bioactivities of anth ocyanins in Cornus species. Journal of agricultural a nd food chemistry. 2002 Apr 24;50(9):2519-23.

2. Noguchi N and Niki E. Diet Nutrition and Health. 2 Othed. Papas M. P., CRC Press, Florida.1999.

3. Middleton E, Kandaswami C, Theoharides TC. The effects of plant flavonoids on mammalian cells: impl ications for inflammation, heart disease, and cancer. Pharmacological reviews. 2000 Dec 1;52(4):673-75 1.

4. Barlow SM. Toxicological aspects of antioxidants us ed as food additives. InFood antioxidants 1990 (pp. 253-307). Springer, Dordrecht.

5. Velioglu YS, Mazza G, Gao L, Oomah BD. Antioxi dant activity and total phenolics in selected fruits, ve getables, and grain products. Journal of agricultural and food chemistry. 1998 Oct 19;46(10):4113-7.

6. Vohra SB, Garg SK, Chaudhary RR. Antifertility s creening of plants III. Effect of six indigenous pla nts on early pregnancy in albino rats. Indian J Med ical Research.1969; 57: 893.

7. Lobo R, Prabhu KS, Shirwaikar A, Shirwaikar A. C urcuma zedoaria Rosc.(white turmeric): a review of $\mathrm{i}$ ts chemical, pharmacological and ethnomedicinal pr operties. Journal of Pharmacy and Pharmacology. 20 09 Jan;61(1):13-21.

8. Kim JE, Choi NH, Kang SC. Anti-listerial properties of garlic shoot juice at growth and morphology of $\mathrm{Li}$ steria monocytogenes. Food Control. 2007 Oct 1;18( 10):1198-203.

9. Sonibare MA, Moody JO, Adesanya EO. Use of me dicinal plants for the treatment of measles in Nigeria . Journal of ethnopharmacology. 2009 Mar 18;122(2 ):268-72.

10. Idika N. A textbook of Medicinal plants: The diver sity of uses of Medicinal plants in Nigeria. 2008.

11. Rahman A, Al-Reza SM, Siddiqui SA, Chang T, K ang SC. Antifungal potential of essential oil and eth anol extracts of Lonicera japonica Thunb. against $d$ ermatophytes. EXCLI journal. 2014;13:427. 
12. Ilori M, Sheteolu AO, Omonibgehin EA and Ade neye AA, Antibacterial activity of Ocimumgratiss imum (Lamiaceae) J. Diarrhoeal Dis. Res.1996; 1 4: 283-285.

13. Faria TD, Ferreira RS, Yassumoto L, Souza JR, Ish ikawa NK, Barbosa AD. Antifungal activity of esse ntial oil isolated from Ocimum gratissimum L.(eug enol chemotype) against phytopathogenic fungi. $\mathrm{Br}$ azilian archives of biology and technology. $2006 \mathrm{~N}$ ov;49(6):867-71.

14. Mohammed A, Tanko Y, Okasha MA, Magaji R A, Yaro AH. Effects of aqueous leaves extract of Ocimumgratissimum on blood glucose levels of st reptozocin induced diabetic wistar rats. Afr. J. Bi otechnol. 2007; 6(18): 2087-2090.

15. Halliwell B, Gutteridge JMC. Free radicals in biolo gy and medicine. Oxford University Press, Oxford, USA, 1999.

16. Chandrasekaran M, Venkatesalu V. Antibacterial an $\mathrm{d}$ antifungal activity of Syzygium jambolanum seed s. Journal of ethnopharmacology. 2004 Mar 1;91(1): 105-8.

17. Demirtas I, Erenler R, Elmastas M, Goktasoglu A. S tudies on the antioxidant potential of flavones of All ium vinealeisolated from its water-soluble fraction. Food Chem. 2013; 136: 34-40.

18. Rahman A, Bajpai VK, Dung NT, Kang SC. Antiba cterial and antioxidant activities of the essential oil a nd methanol extracts of BidensfrondosaLinn. Int J F ood Sci Tech. 2011; 46:1238-1244

19. Deak T and Beuchat LR. Handbook of food spoilag e. New York, USA: CRC Press.1996.

20. Periasamy VS, Athinarayanan J, Alshatwi AA. Anti cancer activity of an ultrasonic nanoemulsion formu lation of Nigella sativa L. essential oil on human bre ast cancer cells. Ultrasonics sonochemistry. $2016 \mathrm{Ju}$ 1 1;31:449-55.

21. Chu Y, Chang C, Hsu H. Flavonoid content of sever al vegetables and their antioxidant activity. J Sci Fo od Agric. 2010; 80: 561-566.

22. Yang D, Xie H, Jiang Y, Wei X. Phenolics from stra wberry cv. Falandi and their antioxidant and $\alpha$-gluc osidase inhibitory activities. Food Chem. 2016; 194 : 857-863.

23. Cuendet M, Hostettmann K, Potterat O, Dyatmiko $\mathrm{W}$. Iridoid glucosides with free radical scavenging $\mathrm{p}$ roperties from Fagraea blumei. Helvetica Chimica Acta. 1997 Jun 30;80(4):1144-52.

24. Lister E, Wilson P. Measurement of total phenolics and ABTS assay for antioxidant activity (personal $\mathrm{c}$ ommunication). Crop Research Institute, Lincoln, $\mathrm{N}$ ew Zealand. 2001:235-9.

25. Karamanoli K. Secondary metabolites as allelochem icals in plant defence against microorganisms of the phyllosphere. Allelopathy: from molecules to ecosy stems. USA-Enfield (NH): Science Publishers Inc. 2 002:277-88. 